\title{
Sufism and Challenges of Modern Science:
}

\section{Nasr's Perspective}

SeyedAmirHossein Asghari

Indiana University Bloomington

sasghari@iu.edu

ORCID: 0000-0001-8850-7591

\section{Abstract}

If the universe is defined as a manifestation of the Divine in the Alevi-Bektashi and other Sufi thoughts, what are their responses to modern dominant philosophy and science that is fundamentally secular and leaves no space for the Sacred? Sufism is a broad and diverse movement within the history of Islam. It nevertheless represents a Divine-centric cosmology in which God -through His creation- is invisibly visible, and $\mathrm{He}$ is at the same time, the eternal and inward reality of the external and visible world. In other words, God is the eternal meaning of everything. This paper will study the question of philosophical assessment of modern philosophy and scientific world-view from a Sufi perspective. In particular, it will examine the phenomenon of modern science and technology from the perspective of the Sufi and traditionalist school of Islam. Thereupon, this paper aims to outline and examine the question of Sacred in confrontation of Secular in the context of Sufism and philosophy. For a Sufi-philosophical thought, this work will assess the idea of reviving sacred or religious science mostly elaborated in the works of Nasr. As a prominent figure of the Traditionalist School, also a Sufi of the Shādhili order, Nasr (b.1933) emphasizes throughout his works on the necessity of recovering "Religious and Sacred Science". Embedded in this suggestion lies a critique of modern science and technology as well. The mentioned view, according to him, is religious, and the term "sacred science" in his works is juxtaposed to modern science. Furthermore, this paper investigates Nasr's critiques of modern science's fundamental philosophical principles as determining its secular nature in opposition to the notion of sacred science and world view in Sufism. 


\section{Keywords}

Alevi-Bektashi; Sufism, Modern Science; Traditional Science; Sacred Science;

Seyyed Hossein Nasr; Secular Science 


\section{References}

Asghari, S. (2017). Ontology and Cosmology of the 'aql in Șadrā's Commentary on Ușūl alKāfì. Journal of Shi'a Islamic Studies, 10(2), 157-182.

Asghari, S. (2021). Intellect and Revelation- Notes on Mullā Șadrā Shīrāzì's Approach in His Commentary on Usul Al-Kafi.docx.

Asghari, S. A. (2016). Sufi Interpretation of the Qur'ān. Burhan Journal of Qur'anic Studies, $1(1), 28-45$.

Baharlu, İ. (2020). Şah'ın Bahçesinde Şah İsmail Öncesi ve Sonrası Kızılbaşlık. İstanbul: Kitabevi Yayınları.

Chittick, W. C. (2007). Science of the cosmos, science of the soul: the pertinence of Islamic cosmology in the modern world. Oxford: Oneworld.

Chittick, W. C. (2012). The Goal of Islamic Education. In J. Casewit (Ed.), Education in the light of tradition. Bloomington, Ind.; London: World Wisdom; Deep [distributor].

Deane-Drummond, C. (2017). Pierre Teilhard de Chardin on people and planet. Retrieved from

https://search.ebscohost.com/login.aspx?direct=true \&scope $=$ site $\& d b=n l e b k \& d b=n l a b$ k\&AN=1550699

Descartes, R., Cottingham, J., \& Williams, B. (2017). Meditations on first philosophy: with selections from the Objections and replies (Second Edition. ed.). Cambridge, United Kingdom; New York: Cambridge University Press.

Descartes, R., \& Maclean, I. (2006). A discourse on the method of correctly conducting one's reason and seeking truth in the sciences. Oxford; New York: Oxford University Press.

Fernando, R., Coomaraswamy, A. K., \& Sri Lanka Institute of Traditional, S. (1999). The Unanimous tradition: essays on the essential unity of all religions. Colombo: Sri Lanka Institute of Traditional Studies.

Guénon, R. (1946). La crise du monde moderne. Paris: Gallimard.

Guénon, R. (1987). Orient et Occident. Paris: Éd. de la Maisnie.

Guénon, R. (2001). The crisis of the modern world (4th, rev. ed.). Ghent, NY: Sophia Perennis.

Guénon, R., \& Herlihy, J. (2009). The essential René Guénon: metaphysics, tradition, and the crisis of modernity. Bloomington, Ind.

San Rafael, Calif.: World Wisdom ;

Sophia Perennis.

Kalin, I. (2001). The Sacred versus the Secular: Nasr on Science. In R. E. Auxier, L. E. Hahn, \& L. W. Stone (Eds.), The philosophy of Seyyed Hossein Nasr (Vol. 28). Chicago: Open Court.

LEGENHAUSEN, H. M. (2002). Why I Am Not a Traditionalist. Retrieved from https://english.religion.info/wp-content/uploads/2016/08/2002 legenhausen.pdf

Matthew, M.-K. (2017). Powers of One: The Mathematicalization of the Occult Sciences in the High Persianate Tradition. Intellectual History of the Islamicate World, 5(1), 127 199. doi:https://doi.org/10.1163/2212943X-00501006

Matthew, M.-K. (2019). How to Rule the World: Occult-Scientific Manuals of the Early Modern Persian Cosmopolis. Journal of Persianate Studies, 11(2), 140-154. doi:https://doi.org/10.1163/18747167-12341325

Mehta, N. (2011). Mind-body Dualism: A critique from a Health Perspective. Mens sana monographs, 9(1), 202-209. doi:10.4103/0973-1229.77436 
Melvin-Koushki, M. (2020). Is (Islamic) Occult Science Science? Theology and Science, 18(2), 303-324. doi:10.1080/14746700.2020.1755547

Mulla Sadra, S. (2001-5). Al-Hikma al-muta' 'aliya fi-l-as far al- 'aqliyya al-arba' a [The Transcendent Philosophy of the Four Journeys of the Intellect] (Vol. 5). Tehran: Bunyād-i Sadra.

Nasr, S. H. (1968a). The encounter of man and nature: the spiritual crisis of modern man. London: Allen \& Unwin.

Nasr, S. H. (1968b). Science and civilization in Islam. Cambridge, Mass., Harvard University Press.

Nasr, S. H. (1983). Reflections on Islam and Modern Thought. Studies in Comparative Religion, 15(3\&4). Retrieved from www.studiesincomparativereligion.com

Nasr, S. H. (1989). Knowledge and the sacred. Albany: State University of New York Press.

Nasr, S. H. (1996). Religion and the order of nature. New York: Oxford University Press.

Nasr, S. H. (2006). In the Beginning, was Consciousness. Retrieved from http://www.worldwisdom.com/public/viewpdf/default.aspx?articletitle=In the Beginning was Consciousness by Seyyed Hossein Nasr.pdf. Retrieved 06/28/2010, from World Wisdom http://www.worldwisdom.com/public/viewpdf/default.aspx?articletitle=In_the_Beginning_was_Consciousness_by_Seyyed_Hossein_Nasr.pdf

Nasr, S. H., \& Iqbal, M. (2007). Islam, science, Muslims, and technology. Kuala Lumpur Sherwood Park, Alberta, Canada: Islamic Book Trust ;

Al-Qalam Pub.

Nasr, S. H., Sivin, N., \& Smith, H. (1973, 1973). Contemporary man: between the rim and the axis. Paper presented at the Technology and Culture Seminar, [Cambridge, Mass.].

Rizvi, S. (2019). "Mulla Sadra. In E. N. Zalta (Ed.), The Stanford Encyclopedia of Philosophy (Spring 2019 Edition): Stanford University.

Sari, E. (2016). Asiklarimiz. Antalya, Turkey: Noktaekitap.

Seattle, C. (1854). Chief Seattle's LETTER TO ALL. Retrieved from http://www.csun.edu/ vcpsy00h/seattle.htm

Sideris, L. H. (2018). Consecrating science: wonder, knowledge, and the natural world. Oakland, California: University of California Press.

Smith, H. (2001). NASR'S DEFENSE OF THE PERENNIAL PHILOSOPHY. In R. E. Auxier \& L. Stone (Eds.), The philosophy of Seyyed Hossein Nasr. Chicago: Open Court.

Spicker, S. F. (1994). The Philosophy of the body: rejections of Cartesian dualism. Malabar, Fla.: Krieger Pub. Co. 